\title{
Detection and Pulsed-Field Gel Electrophoresis Typing of Listeria monocytogenes Isolates from Milk Vending Machines in Croatia
}

\author{
Nevijo Zdolec ${ }^{1, *(D)}$, Dean Jankuloski ${ }^{2}$, Marta Kiš ${ }^{1}$, Brigita Hengl ${ }^{3}$ (D) and Nataša Mikulec ${ }^{4}$ \\ 1 Department of Hygiene, Technology and Food Safety, Faculty of Veterinary Medicine, University of Zagreb, \\ Heinzelova 55, 10000 Zagreb, Croatia \\ 2 Food Institute, Faculty of Veterinary Medicine in Skopje, University "Ss' Cyril and Methodius", \\ 1000 Skopje, Macedonia \\ 3 Center for Food Safety, Croatian Agency for Agriculture and Food, Ivana Gundulića 36b, \\ 31000 Osijek, Croatia \\ 4 Department of Dairy Science, Faculty of Agriculture, University of Zagreb, Svetošimunska 25, \\ 10000 Zagreb, Croatia \\ * Correspondence: nzdolec@vef.hr; Tel.: +38-51-239-0199
}

Received: 14 April 2019; Accepted: 16 July 2019; Published: 19 July 2019

\begin{abstract}
The aim of the present study was to evaluate the persistence of Listeria monocytogenes in raw milk from vending machines, based on culture and molecular detection of pathogen and Pulsed-Field Gel Electrophoresis typing. From December 2015 to January 2017, a total of 319 milk samples from 36 vending machines were examined for the presence and count of L. monocytogenes by reference methods ISO 11290:1 and ISO 11290:2. Molecular detection of pathogens was performed by loop-mediated isothermal DNA amplification (LAMP) coupled with bioluminescence (Molecular Detection Assay). L. monocytogenes was detected by MDA in 14 milk samples (4.38\%) from four farms, compared to eight positive samples $(2.5 \%)$ retrieved by a reference ISO method. Cultivable L. monocytogenes isolates were subjected to Pulsed-Field Gel Electrophoresis typing and pulsotypes were compared with those obtained during the previous survey in Croatia (2014-2015). It was found that identical PFGE patterns of L. monocytogenes occur in milk samples of the same producer over a three-year period, indicating the persistence of pathogens in raw milk vending machines. The results obtained support the need for more effective control of milk in the entire food chain.
\end{abstract}

Keywords: raw milk; milk vending machine; Listeria monocytogenes; Molecular Detection Assay; Pulsed-Field Gel Electrophoresis

\section{Introduction}

Consumption of raw milk is popular in some European countries (e.g., Italy, the UK), including Croatia, due to a belief in the health benefits of such milk and the trend for consuming raw or unprocessed foods. In Croatia, raw milk may be placed on the market via milk vending machines (81 registered milk vending machines as of April 2019; Veterinary and Food Safety Directorate) and consumed after boiling (recommendations for consumers). Boiling the milk is the only method for ensuring microbiological safety [1,2]; however, the responsibility is in the hands of the consumers, who often underestimate the risks associated with the consumption of raw milk [3]. It is estimated that $50 \%$ of Croatian buyers of milk from vending machines consume the milk without thermal treatment [4]. Raw milk can be contaminated by different pathogenic bacteria such as Campylobacter, Salmonella, Shiga toxin-producing Escherichia coli (STEC), and Listeria monocytogenes [5]. The presence of L. monocytogenes in unpasteurized milk and cases of human listeriosis due to the consumption of 
raw milk have been described worldwide [6-8]. Hence, surveys or monitoring programs covering foodborne pathogens in raw milk are necessary to prevent an adverse influence on human health. For instance, a study in Italy revealed that $0.3 \%$ of samples were positive for Salmonella, $0.2 \%$ were positive for E. coli O:157, 1.5\% were positive for Campylobacter spp., and 1.6\% were positive for Listeria monocytogenes. The authors reported a statistically significant correlation between the previous finding of the pathogen and re-contamination [9]. In Croatia, 87 milk samples from 30 vending machines were tested in 2014 and 2015, and four samples from two producers were positive for L. monocytogenes [4].

The aim of the present study was to evaluate the persistence of L. monocytogenes in raw milk from vending machines based on survey data from three sampling years and comparison of L. monocytogenes pulsotypes. In addition to the standard cultured method, Molecular Detection Assay (MDA) was used to detect samples with very low contamination levels.

\section{Materials and Methods}

\subsection{Milk Samples}

A total of 319 milk samples were collected from 36 vending machines located in Croatia, in the cities of Zagreb $(n=194)$ and Sisak $(n=15)$, and in Zagreb County $(n=110)$, from December 2015 to January 2017. The samples were kept in sterile sample bottles $(1 \mathrm{~L})$, transported in a portable cooler $\left(4{ }^{\circ} \mathrm{C}\right)$, and analyzed within one hour after reaching the microbiological laboratory of the Hygiene, Technology and Food Safety Department, Faculty of Veterinary Medicine, University of Zagreb.

\subsection{Microbiological Analyses}

Detection and enumeration of L. monocytogenes in raw milk samples were performed using ISO 11290:1 and ISO 11290:2 methods, respectively [10,11]. In parallel, the presence of L. monocytogenes was determined by loop-mediated isothermal DNA amplification (LAMP) method coupled with bioluminescence (Molecular Detection Assay; MDA, 3M, St. Paul, MN, USA) [12]. For the MDA analysis, $25 \mathrm{~mL}$ of the sample was pre-enriched in Demi-Fraser Broth Base (3M) for $24 \mathrm{~h}$ at $37^{\circ} \mathrm{C}$, and enriched in Fraser Broth Base (3M) for $24 \mathrm{~h}$ at $37^{\circ} \mathrm{C}$. After incubation, the protocol recommended by the manufacturer was followed. In addition to isolates obtained in this study (December 2015-January 2017), the isolates from a previous survey [4] were recovered for the purpose of PFGE typing.

\subsection{Pulsed-Field Gel Electrophoresis Typing of Listeria monocytogenes}

L. monocytogenes isolates obtained during two Croatian surveys were typed by Pulsed-Field Gel Electrophoresis (PFGE) using a standardized laboratory protocol for Listeria monocytogenes in one day [13], with modification by using one restriction enzyme (ApaI). An analysis of the obtained restriction enzyme digestion patterns was made with FPQuest V.5.10. software (Bio-Rad, Hercules, CA, USA). The similarity between patterns was calculated with the Dice coefficient. The Unweighted Pair Group Method (UPGMA) was used for dendrogram construction. The tolerance of the position was set at $1.5 \%$, while the optimization was $0.5 \%$.

\section{Results and Discussion}

Using MDA, 14 samples (4.38\%) were positive for the presence of L. monocytogenes and came from four different producers. On the other hand, only eight positive samples $(2.5 \%)$ were detected by the ISO method, with counts ranging from 50 to $100 \mathrm{cfu} / \mathrm{mL}$ (Table 1). All samples positive by MDA and negative by ISO methods have a low amount of the pathogen, i.e., below the limit of detection $(<10 \mathrm{cfu} / \mathrm{mL})$. 
Table 1. Comparison of L. monocytogenes detection results in milk samples by cultural and molecular methods (MDA).

\begin{tabular}{cccc}
\hline Sample ID & Molecular Detection Assay & HRN ISO 11290:1 & HRN ISO 11290:2 (cfu/mL) \\
\hline 1 & + & + & 60 \\
2 & + & + & 50 \\
3 & + & - & $<10$ \\
4 & + & - & $<10$ \\
5 & + & + & 90 \\
6 & + & - & $<10$ \\
7 & + & - & $<10$ \\
8 & + & - & $<10$ \\
9 & + & + & 60 \\
10 & + & - & $<10$ \\
11 & + & + & 70 \\
12 & + & + & 100 \\
13 & + & + & 60 \\
14 & + & + & 50 \\
\hline
\end{tabular}

The incidence of L. monocytogenes in this study is similar to a previous survey of milk vending machines in Croatia (2014-2015), in which four samples $(n=87,4.59 \%)$ were contaminated with the pathogen [4]. In Italy, $0.5 \%$ of milk from vending machines was positive for L. monocytogenes and characterized by low contamination levels [14]. Torkar et al. [15], in Slovenia, reported that the quantity of L. monocytogenes in raw milk was below $10 \mathrm{cfu} / \mathrm{mL}$. However, it should be noted that in the present study, using a molecular procedure, a higher number of Listeria-positive samples was detected compared to the standard reference method. It is also important to note that the MDA method significantly reduces the time required to obtain the results (presence/absence of L. monocytogenes), which can be relevant for risk assessment as well as to promptly improve hygienic measures. Giacometti et al. [3] also reported the lower sensitivity of cultural methods of pathogen detection in raw milk compared to molecular methods.

Considering the possibility of L. monocytogenes' persistence in the production and distribution of raw milk, PFGE patterns were compared between isolates obtained in both Croatian surveys (Figure 1) that originated from the same farm. 


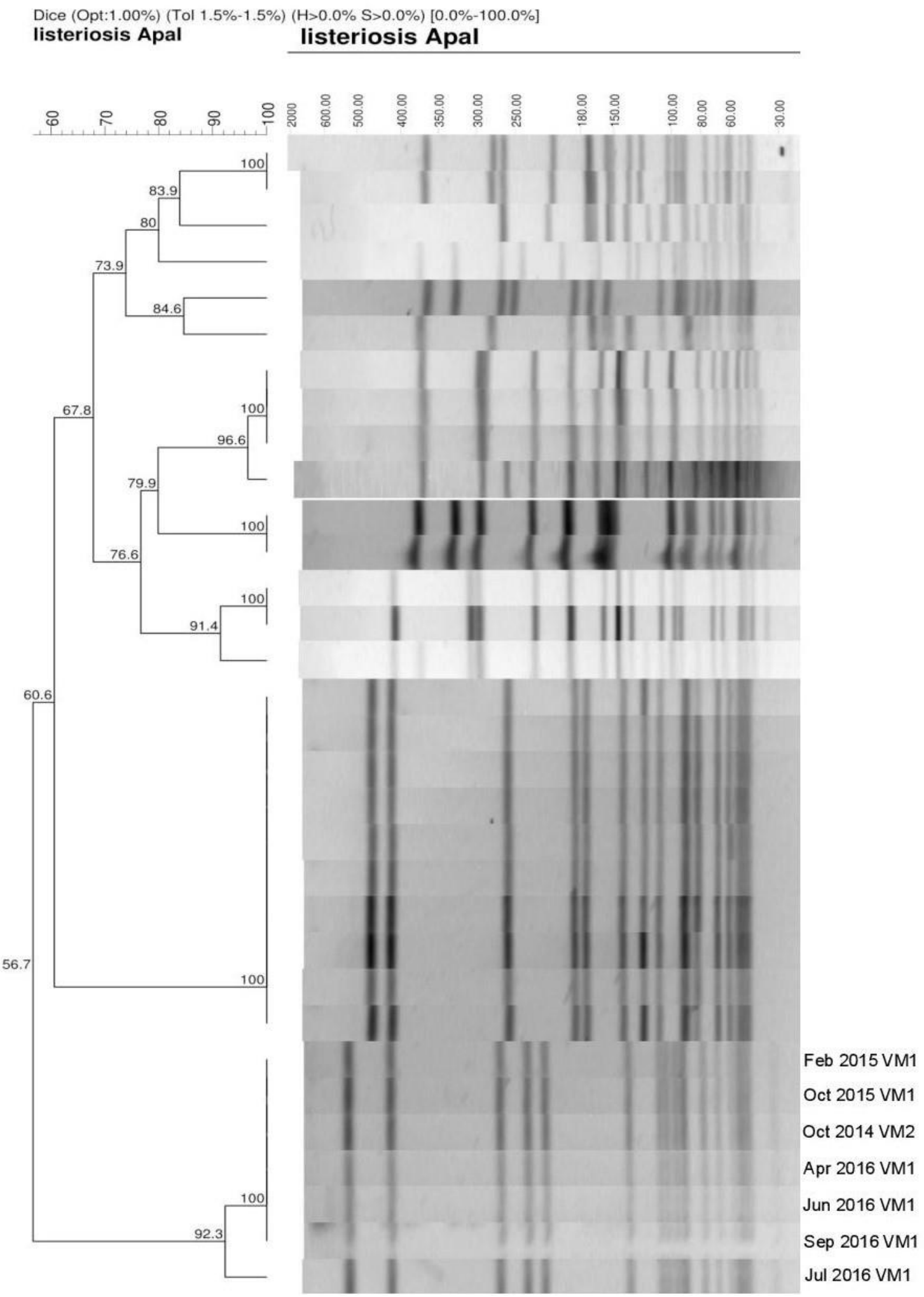

Figure 1. Pulsed-Field Gel Electrophoresis (PFGE) patterns restricted with ApaI enzyme. Marked lines 1-3 present isolates patterns from the first survey (2014-2015), lines 4-7 are isolates from presented study (2016/2017). VM1, VM2 = vending machines from the same producer.

It was found that identical PFGE patterns of L. monocytogenes appeared in milk from the same producer collected from two vending machines during four samplings in April, June, and September 
2016. When comparing these patterns with the profiles of previously collected isolates (Figure 1, lines 1-3), no differences were found, indicating pathogen persistence in the same farm and vending machines. Gelbícová and Karpísková [16] reported that macrorestriction analysis revealed a considerable heterogeneity of profiles, with nine different pulsotypes being detected in raw milk from the Czech Republic. In line with our results, Tahoun et al. [17] reported high genetic relatedness between L. monocytogenes isolates recovered from raw milk, milk equipment, and farm workers. Castro et al. [18] have found only two pulsotypes that occurred in multiple samples of raw milk.

\section{Conclusions}

The majority of farmers selling milk directly through vending machines are aware of the importance of milk hygiene procedures and the microbiological safety of raw milk. The presence of $L$. monocytogenes was characteristic of samples of poor hygienic quality (a high number of other bacteria; data not shown) and always related to the same producers. Proof of this is the finding of identical PFGE patterns of L. monocytogenes isolates during three-year milk sampling of the same vending machines of individual producers, indicating a persistent risk for consumers and requiring systematic control of raw milk production and distribution. Since pulsotypes cannot be compared among studies, further work on collected L. monocytogenes strains will include multilocus sequence typing (MLST) for providing valuable information on the circulating sequence types in Croatia.

Author Contributions: N.Z. designed the study, performed the microbiological analyses, and wrote the paper; D.J. performed the PFGE analyses and interpreted the results; M.K. collected and interpreted the results; B.H. edited the manuscript; N.M. and D.J. contributed materials/resources.

Funding: This study was conducted as part of the research project "Innovative technology in vending machines control in order to increase the quality and competitiveness of milk producers," financed by the Ministry of Agriculture, Agricultural Research Council (Project No. 2015-13/69).

Conflicts of Interest: The authors declare no conflict of interest.

\section{References}

1. Tremonte, P.; Tipaldi, L.; Succi, M.; Pannella, G.; Falasca, L.; Capilongo, V.; Coppola, R.; Sorrentino, E. Raw milk from vending machines: Effects of boiling, microwave treatment, and refrigeration on microbiological quality. J. Dairy Sci. 2014, 97, 3314-3320. [CrossRef] [PubMed]

2. Czyżak-Runowska, G.; Wójtowski, J.; Niewiadomska, A.; Markiewicz-Keszycka, M. Quality of fresh and stored mare's milk. Mljekarstvo 2018, 68, 108-115. [CrossRef]

3. Giacometti, F.; Serraino, A.; Finazzi, G.; Daminelli, P.; Losio, M.N.; Tamba, M.; Garigliani, A.; Mattioli, R.; Riu, R.; Zanoni, R.G. Field handling conditions of raw milk sold in vending machines: Experimental evaluation of the behaviour of Listeria monocytogenes, Escherichia coli O157:H7, Salmonella Typhimurium and Campylobacter jejuni. Ital. J. Anim. Sci. 2012, 11, 132-136. [CrossRef]

4. Croatian Food Agency. Scientific Opinion on Public Health Risk Related to Raw Milk Consumption. Available online: https:/www.hah.hr/wp-content/uploads/2016/12/znanstveno-misljenje-o-javno-zdravstvenomriziku-vezanom-za-konzumaciju-sirovog-mlijeka.pdf (accessed on 4 November 2018).

5. EFSA: Panel on Biological Hazards. Scientific Opinion on the public health risks related to the consumption of raw drinking milk. EFSA J. 2015, 13, 3940. [CrossRef]

6. Latorre, A.A.; Pradhan, A.K.; Van Kessel, J.A.; Karns, J.S.; Boor, K.J.; Rice, D.H.; Mangione, K.J.; Gröhn, Y.T.; Schukken, Y.H. Quantitative risk assessment of listeriosis due to consumption of raw milk. J. Food Prot. 2011, 74, 1268-1281. [CrossRef] [PubMed]

7. Hunt, K.; Drummond, N.; Murphy, M.; Butler, F.; Buckley, J.; Jordan, K. A case of bovine raw milk contamination with Listeria monocytogenes. Ir. Vet. J. 2012, 65, 13. [CrossRef] [PubMed]

8. Owusu-Kwarteng, J.; Wuni, A.; Akabanda, F.; Jespersen, L. Prevalence and Characteristics of Listeria monocytogenes Isolates in Raw Milk, Heated Milk and Nunu, a Spontaneously Fermented Milk Beverage, in Ghana. Beverages 2018, 4, 40. [CrossRef] 
9. Bianchi, D.M.; Barbaro, A.; Gallina, S.; Vitale, N.; Chiavacci, L.; Caramelli, M.; Decastelli, L. Monitoring of foodborne pathogenic bacteria in vending machine raw milk in Piedmont. Food Control 2013, 32, 435-439. [CrossRef]

10. ISO. ISO 11290-1:2017 Microbiology of the Food Chain-Horizontal Method for the Detection and Enumeration of Listeria Monocytogenes and of Listeria spp._-Part 1: Detection Method; ISO: Geneva, Switzerland, 2017.

11. ISO. ISO 11290-2:2017 Microbiology of the Food Chain-Horizontal Method for the Detection and Enumeration of Listeria Monocytogenes and of Listeria spp.-Part 2: Enumeration Method; ISO: Geneva, Switzerland, 2017.

12. Pažin, V.; Jankuloski, D.; Kozačinski, L.; Dobranić, V.; Njari, B.; Cvrtila, Ž.; Lorenzo, J.M.; Zdolec, N. Tracing of Listeria monocytogenes Contamination Routes in Fermented Sausage Production Chain by Pulsed-Field Gel Electrophoresis Typing. Foods 2018, 7, 198. [CrossRef] [PubMed]

13. PulseNet, PFGE Protocols. Available online: https://www.cdc.gov/pulsenet/pdf/listeria-pfge-protocol508c. pdf (accessed on 13 February 2019).

14. Dalzini, E.; Bernini, V.; Bertasi, B.; Daminelli, P.; Losio, M.N.; Varisco, G. Survey of prevalence and seasonal variability of Listeria monocytogenes in raw cow milk from Northern Italy. Food Control 2016, 60, 466-470. [CrossRef]

15. Godic Torkar, K.; Kirbiš, A.; Vadnjal, S.; Biasizzo, M.; Galicic, A.; Jevšnik, M. The microbiological quality of Slovenian raw milk from vending machines and their hygienic-technical conditions. Br. Food J. 2017, 119, 377-389. [CrossRef]

16. Gelbícová, T.; Karpísková, R. Occurrence and typing of Listeria monocytogenes isolated from raw cow's milk collected on farms and from vending machines. Klin. Mikrobiol. A Infekcni Lek. 2012, 18, 38-42.

17. Tahoun, A.B.M.B.; Abou Elez, R.M.M.; Abdelfatah, E.N.; Elsohaby, I.; El-Gedawy, A.A.; Elmoslemany, A.M. Listeria monocytogenes in raw milk, milking equipment and dairy workers: Molecular characterization and antimicrobial resistance patterns. J. Glob. Antimicrob. Resist. 2017, 10, 264-270. [CrossRef] [PubMed]

18. Castro, H.; Ruusunen, M.; Lindström, M. Occurrence and growth of Listeria monocytogenes in packaged raw milk. Int. J. Food Microbiol. 2017, 261, 1-10. [CrossRef] [PubMed] 